\title{
ETHICAL INTERPRETATION OF THREE ELEMENTS OF MEDICINE DURING COVID-19
}

\author{
O.I. Kubar \\ $P h D$, leading scientific researcher, laboratory for etiologic and control of viral infections, \\ Saint-Petersburg Pasteur Institute; member of the national bioethics committee under Commission of Russia for UNESCO; \\ ex-memberIBC UNESCO,St.Petersburg,okubar@list.ru
}

The humanitarian idea underlying this article is to attempt an epidemiological interpretation of the classic Hippocratic triad "Medicine consists of three elements: the disease, the patient and the doctor". In the XIII century, the Syrian doctor Abul-Faraj in his saying: "Look, there are three of us - you, me, and the disease. If you are on my side, it will be easier for the two of us to defeat her. But, if you go over to her side, I alone will not be able to defeat you both" deciphered the magical meaning of these words. For centuries, the fundamental integrity of this formula has been an ethical and professional guarantee of the success of each patient's treatment and the prospect of building a personalized healthcare system. In this particular article, we have searched for new content of three key elements of the textbook aphorism in the context of the COVID-19 pandemic. An understanding of the role of the doctor - "I" as the whole complex of efforts aimed at fighting the pandemic. Patient status "You" means the whole society during a pandemic, and even is as a long-term message for the physical, mental, social and geopolitical health of future generations. The meaning of "Disease" should be understood from the perspective of the problems of the entire health system and logistical ignorance, which has become an obstacle to achieving ethical integrity in managing epidemic challenges. The paper shows how adherence to the ethical principles of social responsibility, trust, and solidarity should become the moral accompaniment of the entire complex of sanitary, anti-epidemic, economic, legal, and social technologies that can ensure success in the fight against the pandemic and prevent the development of unjustified risks.

Key words: COVID-19 pandemic, social responsibility, professional responsibility, trust, solidarity.

\section{ЭТИЧЕСКАЯ ИНТЕРПРЕТАЦИЯ ТРЕХ ЭЛЕМЕНТОВ МЕДИЦИНЫ В ПЕРИОД СОVID-19}

\section{О.И. Кубарь}

Доктор медищинских наук, ведущиий научный специиалист лаборатории этиологии и контроля вирусных инфекций ФБУН НИИ эпидемиологии и микробиологии имени Пастера, член Российского комитета по биоэтике при Комиссии Российской Федерации по делам ЮНЕСКО, член Международного комитета по биоэтике ЮНЕСКО, член Правления Европейского Форума по качественной клинической практике,

экс-председатель Форума комитетов по этике государств-участников СНГ, г. Санкт-Петербург, оkиbаr@list.ru

Гуманитарная идея, положенная в основу данной статьи, направлена на попытку эпидемиологической интерпретации классической триады Гиппократа: «Медицина состоит из трех элементов: болезнь, больной и врач». В ХІІІ веке сирийский врач Абуль-Фараджа в своем изречении «Смотри, нас трое - я, ты и болезнь. Если ты будешь на моей стороне, нам, двоим, будет легче одолеть ее. Но если ты перейдешь на ее сторону, я один не в состоянии буду одолеть вас обоих» расшифровал магический смысл этих слов. На протяжении веков фундаментальная цельность данной формулы является этической и профессиональной гарантией успеха лечения каждого больного и перспективой строительства персонализированной системы здравоохранения В рамках данной работы осуществлен поиск нового содержания трех ключевых элементов хрестоматийного афоризма в условиях пандемии COVID-19. Представлено понимание роли врача - «Я», как всего комплекса усилий, направленных на борьбу с пандемией. Статус больного «Ты» рассмотрен не только с позиций общества, охваченного эпидемическим кризисом, но и имеет долгосрочный посыл для физического, психического, социального и геополитического здоровья будущих поколений. Значение «Болезнь» осмыслено с позиций проблем всей системы здравоохранения и логистического невежества, ставшего препятствием в достижении этической целостности управления эпидемическими вызовами. В работе показано, каким образом приверженность этическим принципам социальной ответственности, доверия, солидарности должна становиться нравственным сопровождением всего комплекса санитарно-противоэпидемических, экономических, правовых и социальных технологий, способных обеспечить успех в борьбе с пандемией и предотвратить развитие необоснованных рисков.

Ключевые слова: пандемия COVID-19, социальная ответственность, профессиональная ответственность, доверие, солидарность.

The classic foundation for understanding the ethical concept of the pandemics is clearly a thorough study of the epidemic legacy. The centuries-old panorama of the pandemics can serve as a kind of archive for searching for the answers to the ethical problems of interaction of various social components that determine the outcome of the fight against infection. The lessons learned, reflected in the world epic, became a moral resource for creating a modern algorithm for ethical management of crisis situations in medicine and determined the direction of searching for answers to the complex challenges of the global epidemic situation caused by COVID-19 [7-9, 12, 13].
The above clearly characterizes the fact that at the time of the development COVID-19, the international community, represented by all interested infrastructures, had a full-fledged baggage of historical memory and knowledge, as well as the entire arsenal of ethical principles in the field of social and behavioral response to a global epidemic disaster. This is the reality that gave rise to the main perplexity of COVID-19, when, against the background of seemingly informational and regulatory sufficiency, the world community faced a certain vacuum in the sphere of ethical and social content of decisions and actions. The latter determined the urgent need for operational 
research of this phenomenon and became the reason for choosing the fundamental platform for this work [10, 11].

Methodical approach. The construction of all the arguments and conclusions of this work lies on the content of the main social groups that made up the allegorical images of "doctor", "patient" and "disease" in the existing reality of COVID-19. The orientation of the formation for different groups was the degree of responsibility, social, professional, and individual, which largely determines the nature of decisions and actions taken.

In the context of a large-scale epidemic threat, the group embodying the image of a "doctor" is complex, interdisciplinary and multi-level. According to the degree of direct participation in the epidemic process, this group primarily includes the infrastructure of the health system, including scientific and practical potential, as well as pharmaceuticals and medical equipment. An important role belongs to managers at all levels, from the system of state authorities, to departmental structures of sanitary and surveillance control and medical-biological links. This group also includes all life-supporting industries, such as transport, construction, food, police, social communication, education, and culture. One of the components of this group that affects the quality of content and dissemination of socially significant information is the media. We should also note the positive contribution of a new social phenomenon of a humanitarian nature - volunteers.

Considering responsibility as a measure of effectiveness of actions, it is necessary to emphasize the presence of different levels of responsibility. Firstly, it is reasonable to focus on professional responsibility to the individual and community for the quality of the actions performed and the results obtained. A great role belongs to social responsibility for ensuring the effectiveness and safety of decisions and actions taken in relation to individuals, civil society, the entire population of the Earth and the environment. Social responsibility also includes the responsibility to prevent or minimize possible negative consequences of certain measures. The responsibility of the media exists in the mode of possible positive or destructive influence on an individual, group or society. It bases in the frame of compliance with the principles of journalistic ethics, and following the ethical standard of providing reliable and objective information. Despite all the complexity and interdependence of responsibility within the described group, the highest gradient of both personal and social components remains the category of health care, which is as close as possible to resolving conflict ethical situations.

When defining the so-called "patient" group, it is clear, that during epidemics, this category legitimately includes each patient, individual groups (for example, risk groups) and the entire society at the scale of a particular country or humanity as a whole. This format, first, changes the priority balance in relation to the interests of the individual and society. In the chosen model of the "doctor/patient" relationship, the aim of "patient" category consists of the responsible individual and social behavior in compliance with all recommendations and requirements defined by the conditions of the epidemic situation. The structure of interaction within the "doctor/patient "is based on the social expediency of the measures recommended by the" doctor "and the patient's trust in these recommendations. This approach is necessary to create a classic single block in the fight against the "disease".

At the same time, "disease" in the context of an epidemic should be considered in the broad sense of the word, both as a factor in the defeat of an individual, and as an epidemic process that engulfs society. However, this definition is peculiar to the purely medical side of the problem. In social and ethical terms, the "disease" acquires features that are even more global. For example, the modern possibility of social networks is comparable in terms of contagiousness to an infectious agent. This factor of direct and accessible information destruction has another burdensome characteristic - lack of control. On the side of "disease", there is another destructive phenomenon fraud. Against the background of often a shortage of products and imperfect actions, scammers use the current agenda for selfish purposes. Thus, the entire given conglomerate "disease" resists the efforts of the category "doctor", and in the case of creating a lobby in the environment of the allegorical group" patient", it is able to negate all therapeutic and anti-epidemic measures.

This is the General plot of the epidemic scenario of the Hippocratic - Abul-Faraj triad. At the same time, in real conditions, each of the selected groups has its own scope and range of providing an ethically comfortable atmosphere for the course of an epidemic/pandemic. At the same time, for each of them there is both a predictable and unpredictable release of ethically destructive risks, the nature and impact of which are parallel to the scale of responsibility and social trust.

Ethical consideration of the current model in the COVID-2019 situation. The logic and emphasis of the analytical approach, first, requires knowledge of the current ethical recommendations, and the degree of their regulatory and administrative inclusion in the national regulatory system, as well as the correct interpretation in the conditions of COVID-2019. Referring directly to the" letter and spirit" of strategic ethical guidelines, it is necessary to emphasize the key ethically significant positions, what include following. First, the obligations and responsibilities of the authorized bodies for organizing assistance to the population during outbreaks of infectious diseases. Second, the possibility of restrictive measures against personal freedom in the interests of public health, which, for example, exclude such measures as the introduction 
of quarantine. Third, the concentration, management and fair distribution of all available resources. Forth, solidarity and coherence of steps at the international level in terms of global management of the situation to regulate activities related, in particular, to the movement of people. Important, that all the stated positions are fully represented in the format of the legal field of the Russian Federation for the period of actions in emergencies, are reflected in the current laws and were included in the operational decision-making agenda of all interested state, departmental and subordinate structures of the Russia [2-6].

Focusing on the fact that the above-mentioned, it can be clearly stated that the point of application for key ethical principles is the group - "doctor". This provision clearly implies the priority social responsibility noted earlier. In addition, it is important to emphasize, that the whole complex of key measures implementation is not possible in principle in the abstract mode of directives, without establishing a mechanism for the division of powers in the field of social responsibility between all components of this group (managers, health care system, life support system, notification system, and others).

At the same time, it is quite possible to assume that there are significant conflicts of professional responsibility deficit. The reasons lie in the background and expected ignorance of certain structures, conditionally defined, for example, as the life support system and the media, in matters of bioethics and medical ethics. This predicted gap, in fact, should be eliminated at the initial stage of interaction, by including an ethical component in the arsenal of documentary support and, in addition, rely on the canons of professional (primarily journalistic) ethics.

A special place in the sphere of ethical responsibility targets on the public health structure, which occupies an unquestionably Central position in terms of personalized involvement in the process of providing medical care. Individual and corporate ethical responsibility, which is essentially a product of education and reflects the entire administrative, moral and regulatory system of relations in the field of health protection, is of key importance.

Based on the described reality, of paramount importance is the relationship of logistics within the group. Thus, the primary social responsibility of managers who in practice do not possess the ethical heritage of medical thinking depends entirely on the quality of training and professional responsibility of physicians.

It is particularly necessary to highlight the ethical pseudo-freedom in the media information space, where it is possible to mix the concepts of objectivity, dosing, accessibility, balance of benefits and risks, confidentiality and conflict of interests. In this regard, it is necessary to note the social, and not only personal, responsibility for the formation of ethical information well-being of the COVID-19 pandemic. Potentially, the information channel of communication within the "doctor/patient" model contains a positive resource for forming the correct attitude to the recommended actions. However, the above-mentioned disregard for ethical principles, on the contrary, can create a barrier to trust and understanding. It is unacceptable to violate the moral canons in medicine, which consist in medical secrecy and confidentiality. These concepts are inviolable not only in relation to a specific patient. Neglect to follow these principles during the epidemic crisis blurs the boundaries of the "doctor/patient" unity.

Speaking of the "disease" factor, in addition to the natural threat caused by the severity of infection, it is necessary to create the strong critical analysis towards to destructive influence of personal irresponsibility. This phenomenon based on ignorance in the field of interpreted issues and unacceptable ease of achieving information goals, characteristic of social networks. It is this format that is responsible for negativity towards the measures recommended by the "doctor", and causes serious damage by spreading false and dangerous information about approaches to treatment and prevention.

Equally significant are the differences in understanding and following bioethics when interpreting the series of guidelines for ethical decision - making during pandemics. The priority set of these principles includes the right to personal freedom, protection from harm, proportionality, and the right to protect privacy, obligations to provide medical care, interaction, fairness, trust and solidarity.

In terms of applying COVID-19 to the actual situation, each of these principles provides an appropriate understanding and relates differently to the ethical powers of the groups highlighted above. Thus, the right to personal freedom in health care crises may be constitutionally restricted in order to protect the entire society. Restrictions on freedom should be carried out in proportion to necessity, appropriately, with minimal measures and fairly. In this situation, the burden of responsibility for decision-making is clearly visible, and the fact that responsibility must be shared in order to ensure that the measures introduced are appropriate. The implementation of the principle of protecting society from harm does not exclude (and often requires) actions of authorized state structures related to the invasion of personal freedoms, which is provided for by current legislation and the rapid response system $[1,4-6]$. The vertical coherence and compatibility of actions used in emergencies (from the Constitutional framework to local self-government bodies, individual organizations and public associations) is extremely important, with the guarantee that human and civil rights and freedoms can be restricted only within the limits required by the severity of the situation. From the point of view of the ethical concept, such a situation has a set control mechanism at the initial and final stages. So the decisions involving the invasion of the sphere of personal freedoms and restrictions 
thereof, must include the balance of mandatory measures to reach agreement on their holding, rationale, providing the reasons for such action and the mechanism of monitoring of decisions and steps in this field. The monitoring activities, as well as the inclusion of a mechanism for operational adjustments, require special developments with mandatory consideration of factors of social psychology and ethical content.

In the same time, both in the course of public discussion in the media and social networks there is a very free movement of provisions in this area. Unfortunately, it is often possible to meet with the inability and ignorance of persons who have assumed the right of judgment. This phenomenon carries an incorrect (i.e. unethical) signal, and the echo of such an unethical action can distort the original essence and morally justified nature of the measures taken. This implies the requirement not only of ethical decision-making, but also of ethical presentation of the latter to society in order to ensure the ultimate goal of ethical actions.

In addition to the obligation to keep the national format of interaction, the extra measures should take place to comply with the obligations arising from international treaties. The list of these measures includes not entail any discrimination of individuals or groups solely on the grounds of gender, race, nationality, language, origin, property and official status, place of residence, attitude to religion, beliefs, membership of public associations, as well as other circumstances. International regulations establish a close relationship between the responsibility of each individual state (represented by its structures) and the implementation of the universal principle of respect for autonomy and human rights. State responsibility comes from the nature of the international legal system, which relies on the state as a means of forming and applying its rules and guides by the dual doctrine of state sovereignty and equality of States. An adequate level of professional knowledge and authority is necessary to solve problems of such a high level of interaction. Examples of a voluntary nature carried out by persons who are unable, due to lack of appropriate training, even to present the resonance of their violations to the global ethical balance are unacceptable.

Obligations to provide medical care and empathy for suffering are an integral part of all professional ethical codes in medicine. Health care workers should adequately assess the requirements for their duty in comparison with other obligations that exist in relation to their own health, their family, and other circumstances that go beyond professional boundaries. In addition, health workers face significant challenges related to the allocation of available resources, the capacity of existing practices, professional debt, and working conditions. Everywhere, the work of medics during the COVID-19 pandemic is a clear example of a unique commitment to duty, which provides the dual essence of professional knowledge and morality and the courage to follow the high level of ethics during unbearable conflicts, provoked during the pandemic.

However, it is not possible to limit professional responsibility only to the collegial circle. Compliance with the principle of "doctor/patient" interaction requires society to support those who bear a disproportionate burden to protect the public interest and take all necessary steps to minimize this burden. Measures to protect the public interest seem to impose a disproportionate burden of responsibility on health workers. Fairness, in the context of ethical standards in healthcare, is the right of every patient to receive the medical care they need. At the same time, the difference between compliance with this right in normal medical practice and during a pandemic is - that in a pandemic situation, a clear criterion for choosing exactly the type of first aid that is necessary to provide to the patient without fail is applicable and should operate. The volume of elective surgical interventions depending on the severity of the health crisis and the provision of emergency or necessary medical care could be limited and may be limited $[5,6]$. It is the urgent point of ethical conflict in medicine.

As noted above, in the period of pandemics, the very concept of the patient paradoxically changes. In the usual canonical sense, it continues to be only for medical professionals; in general, it passes to the whole society. In these conditions, the ethical principle of trust becomes an integral component of the relationship between not only the doctor and the patient, employees and their organizations, civil society and authorized bodies, as well as the basis for interaction of the complex of all involved structures within global international systems. Senior managers and decisionmakers in health care are faced with the need to gain confidence in their actions. It is obvious that trust is the reflection of a multi-component and long-term experience of assessing the quality of medical services and social protection by the population, which dictates an indispensable requirement for stable and guaranteed improvement of the health system in the future, regardless of crises. Epidemics/pandemics clearly reflect the imperfection of existing public health systems, as demonstrated by the current situation of COVID-2019 on a global scale.

In addition to state guarantees regarding the quality of medical products and services, a prerequisite for building trust is the quality of information support for all anti-epidemic measures. The fact of the need of informing the population about the threats related to the epidemic/pandemic and the protective measures must occupy important place in the operational documents authorized services for sanitary and epidemiological control and public health. However, the situation on informing COVID-2019 in the media clearly highlighted the problem of lack of knowledge and / or non-compliance with ethical principles of informing. The selection information blocks, especially in the early 
stage of awareness of the epidemic, sometimes focused on the demonstration of undue showiness of the story, without observing the principles of objectivity, completeness, balance of risks and benefits and availability understanding of the various contingents. Information blocks did not avoid polar positions: factors of intimidation, on the one hand, or the formation of excessive carelessness, which stood on the personal (usually unprofessional) position of the speaker. The latter is especially important, since the principle of informed consent is legally enshrined in the public health system and the quality of information received by an individual and/or society depends on understanding and further follow-up. This, in the end, determines the success of anti-epidemic and medical measures in the management of crises in healthcare (in particular, it forms the adoption and compliance with quarantine and other restrictive measures).

Regarding another priority principle, which is solidarity, it is necessary to note the academic and historical integrity of this ethical Canon, the truth of which based on the experience of many years of fighting infections [7]. However, in the modern world, the development of the pandemic requires the formation of a new view of the process of global solidarity and solidarity of Nations. On a global scale, the pandemic challenges ideas of national sovereignty, secrecy and territorial isolation. At the regional and national level, the pandemic requires solidarity and concerted action within and between different institutions, and calls for a reconsideration of the traditional value of one's own or territorial interests. All existing documents of the UN (UNESCO and WHO) declared these ideas. However, in some cases, the practice of actions during the COVID-19 period demonstrated the opposite, and there was a destructive impact of information relishing of such scenarios. Both of these situations undoubtedly strengthened the position of the "disease" on a global scale, and this will require careful analysis and assessment.

Conclusion. The genius of the Hippocratic triad (doctor, patient, disease), applied to the current epidemic situation COVID-19, highlighted many ethical and social problems, knowledge of which should be considered the key to the formation of a new concept of epidemic protection in the future. Individuals, groups, communities, professional organizations, government agencies and international organizations that work in the field of sanitary and epidemiological surveillance, along with those who provide information, social, legal and other types of support for global processes to combat the pandemic, should be guided by the following ethical standards in their activities:

- significance and social expediency of decisions and operational actions;

- proportionality and adequacy of anti-epidemic measures to existing risks and the level of predicted potential threat, in order to preserve public confidence and well-being;
- information precaution to prevent possible negative impact in the field of social psychology;

- ensuring equal access to all existing resources based on fair prioritization and consideration of the benefit/risk balance;

- collaboration on the base of cooperation, solidarity, monitoring and reporting to civil society on a global scale.

Knowledge of these principles, along with strict adherence to all forms of responsibility, can ensure the ethical competence of authorized bodies and society in solving acute problems in health crisis situations, thanks to an approximation to the classic Canon of "...if you are on my side, it will be easier for both of us to overcome ...".

\section{REFERENCES}

1. Ilesanmi, M.A. Pandemics and problems of limiting human rights. Lawyer, 2018, no. 8, pp. 59-65. (In Russ.).

2. Constitution (Basic Law) of the Russian Federation. Moskow, 2001. 39 p. (In Russ.).

3. On immunization of infectious diseases: Federal Law of 17.09.1998 № 157-FZ (with amendments and additions) [Electronic resource]. Reference and legal system «Consultant Plus». URL: http://www.consultant.ru/document/cons_doc LAW_20315. (In Russ.).

4. On the protection of the population and territories from natural and man-made emergencies: Federal Law of 21.12.1994 № 68-FZ (as amended by 03.07.2019 № 159-FZ) [Electronic resource]. Reference and legal system «Consultant Plus». URL: http://www.consultant.ru/document/cons doc_LAW_5295.

5. On the sanitary and epidemiological welfare of the population: Federal Law of March 30, 1999, No. 52-FZ (with amendments and additions) [Electronic resource]. Reference and legal system "ConsultantPlus». URL: http://www.consultant.ru/document/cons_doc_LAW_22481. (In Russ.).

6. On the state of emergency: Federal Constitutional Law of 30.05.2001 N 3-FKZ (as amended on 03.07.2016) [Electronic resource]. Reference and legal system «ConsultantPlus». URL: http://www.consultant.ru/document/cons doc_LAW_31866. (In Russ.).

7. Ethics of infectious pathology. Ed. O.I. Kubar. St. Petersburg, FBUN NIIEM imeni Pastera Publ., 2014. 116 p. (In Russ.).

8. Addressing ethical issues in pandemic influenza planning. World Health Organization [Electronic resource]. URL: http://www.who.int/ethics/influenza_project/en.

9. Ethical Guidelines in Pandemic Influenza, Prepared by Ethics Subcommittee of the Advisory Committee to the Director [Electronic resource]. February 15, 2007. URL: http:// www.cdc.gov/od/science/phec/panFlu-Ethic-Guidelines.pdf.

10. Gostin, L.O., Hodge J.G. US Emergency Legal Responses to Novel Coronavirus Balancing Public Health and Civil Liberties. JAMA, 2020, vol. 323, no 12, pp. 1129-1132.

11. Kubar, O.I., Bichurina M.A., Romanenkova N.I. Ethical Consideration Regarding COVID-19. EC Microbiology, 2020, SI.02, pp. 14-15.

12. Stand on Guard for Thee. Ethical considerations in preparedness planning for pandemic influenza. A report of the University of Toronto Joint Centre for Bioethics [Electronic resource]. November 2005. URL: http://www.jointcentreforbioethics.ca/people/documents/ upshur_stand_guard.pdf.

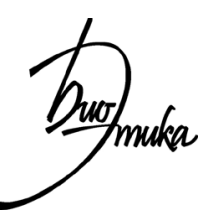

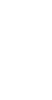


13. UNESCO 21-th Join Session IBC and IGBC [Electronic resource]. Paris, France, 2014. URL: http://www.unesco.org.

\section{ЛИТЕРАТУРА}

1. Илесанми М.А. Пандемии и проблемы ограничения прав человека / Юрист, 2018. - № 8. - С. 59-65.

2. Конституция (Основной закон) Российской Федерации. - М., 2001. - 39 с.

3. Об иммунопрофилактике инфекционных болезней: Федеральный закон от 17.09.1998 № 157-Ф3 (с изменениями и дополнениями) [Электронный ресурс] // СПС «КонсультантПлюс». - URL: http://www.consultant.ru/ document/cons_doc_LAW_20315/

4. О защите населения и территорий от чрезвычайных ситуаций природного и техногенного характера: Федеральный закон от 21.12.1994 № 68-Ф3 (в редакции от 03.07.2019 № 159-Ф3) [Электронный ресурс] // СПС «КонсультантПлюс». - URL: http://www.consultant.ru/ document/cons_doc_LAW_5295/

5. О санитарно-эпидемиологическом благополучии населения: Федеральный закон от 30.03.1999 г. № 52-Ф3 (с изменениями и дополнениями) [Электронный ресурс] // СПС «КонсультантПлюс». - URL: http://www.consultant.ru/document/cons_doc_LAW_22481/

6. О чрезвычайном положении: Федеральный конституционный закон от 30.05.2001 № 3-ФКЗ (ред. от 03.07.2016) [Электронный ресурс] // СПС «Консультант
Плюс». - URL: http://www.consultant.ru/document/cons_ doc_LAW 31866/

7. Этика инфекционной патологии / под общей редакцией О.И. Кубарь. - СПб. : ФБУН НИИЭМ имени Пастера, 2014. - $116 \mathrm{c}$.

8. Addressing ethical issues in pandemic influenza planning. World Health Organization [Electronic resource]. URL: http://www.who.int/ethics/influenza_project/en.

9. Ethical Guidelines in Pandemic Influenza, Prepared by Ethics Subcommittee of the Advisory Committee to the Director [Electronic resource]. - February 15, 2007. - URL: http:// www.cdc.gov/od/science/phec/panFlu-Ethic-Guidelines.pdf.

10. Gostin, L.O. US Emergency Legal Responses to Novel Coronavirus Balancing Public Health and Civil Liberties / L.O. Gostin, J.G. Hodge // JAMA. - 2020. - Vol. 323, № 12. - P. 1129-1132.

11. Kubar, O.I. Ethical Consideration Regarding COVID-19 / O.I. Kubar, M.A. Bichurina, N.I. Romanenkova // EC Microbiology. - 2020. - SI.02. - P. 14-15.

12. Stand on Guard for Thee. Ethical considerations in preparedness planning for pandemic influenza. A report of the University of Toronto Joint Centre for Bioethics [Electronic resource]. - November 2005. - URL: http://www.jointcentreforbioethics.ca/people/documents/ups hur_stand_guard.pdf.

13. UNESCO 21-th Join Session IBC and IGBC [Electronic resource]. - Paris, France, 2014. - URL: http://www.unesco.org

\title{
CROSS-CULTURAL COMMUNICATION IN MEDICAL SETTINGS
}

\author{
V.V.Zhura \\ Doctor of Philology, associate professor, head of the Department of Foreign Languages and Latin, \\ Volgograd State Medical University, \\ Volgograd, ORCID: 0000-0002-8128-701X,vvzhura@gmail.com \\ A.P. Utesheva \\ Senior lecturer, the Department of Foreign Languages and Latin, Volgograd State Medical University, \\ Volgograd, ORCID: 0000-0002-6982-5321, altynai.utesheva@inbox.ru
}

\begin{abstract}
Today there is a strong tendency to incorporate the bioethical principle of social justice in healthcare in cross-cultural communication. Considering cultural differences makes it possible to ensure that the human right to medical care and wellbeing is fully respected. Several types of most vulnerable populations were identified - immigrants and social minorities. When seeking medical care they face a number of problems such as culture and language barriers, lower socio-economic status, lack of literacy, which impede effective communication and care provision. The most promising ways of coping with the problem are developing cultural competence and practicing a patient-centered approach. New curricula aiming at raising cultural awareness have been elaborated for practical use in medical schools.
\end{abstract}

Key words: bioethics, social justice, cross-cultural communication, immigrants, cultural competence, patient centeredness.

\section{МЕЖКУЛЬТУРНАЯ КОММУНИКАЦИЯ В ОБЛАСТИ ЗДРАВООХРАНЕНИЯ}

\author{
B.В. Жура \\ Доктор филологических наук, доцент, заведующий кафедрой иностранных языков с курсом латинского языка, \\ Волгоградский государственный медицинский университет, г. Волгоград, ORCID: 0000-0002-8128-701X, \\ vvzhura@gmail.com
}

\section{А.П. Утешева}

Стариий преподаватель кафедры иностранных языков с курсом латинского языка, Волгоградский государственный медииинский университет, г. Волгоград, ORCID: 0000-0002-6982-5321, altynai.utesheva@inbox.ru

В современных реалиях наблюдается устойчивая тенденция к актуализации в межкультурном общении в области здравоохранения такого принципа биоэтики, как социальная справедливость. Учет культурных различий пациентов, принадлежащих к разным этническим группам, становится гарантией соблюдения права человека на медицинскую помощь и сохранение здоровья. 